\title{
Correlation of CD44v6 and type IV collagen immunohistochemical expression in borderline and malignant surface epithelial tumors
}

\author{
${ }^{\star}$ Mohanad M. Abdul Ghany, ${ }^{* *}$ Mohammed A. AlKurtas, ${ }^{\star * \star}$ Israa T. Hassan
}

\begin{abstract}
Background: the difference in expression of type IV collagen in borderline tumors and ovarian carcinomas has been studied, but the association with adhesion molecules like CD44 have not gain enough interest.

Objectives: The purpose of this study is to assess the expression of CD44v6 and type IV collagen status in borderline tumors and invasive ovarian carcinomas and the correlation between them to define the role of these molecules in tumor invasion and metastasis.

Type of the study: A cross sectional study

Methods: The study included a total of (101) formalin-fixed paraffin-embedded ovarian tissue blocks; of which (19) cases were borderline tumors and (82) cases were overt ovarian carcinomas. Sections from each block were immunohistochemically stained for CD44v6 and type IV collagen.
\end{abstract}

Results: CD44v6 was significantly correlated with FIGO stage of borderline tumors $(p=0.001)$ and ovarian carcinoma $(<0.001)$ and with histological grade of ovarian carcinomas $(p=0.004)$. There was significantly higher expression of type IV collagen in borderline tumors compared to invasive carcinoma $(p<0.001)$ this significance was also seen in correlation to age, stage and grade of the invasive carcinoma, no significant differences in other clinicopathological features were found. There was negative correlation between CD44 v6 \& type IV collagen which was statistically significance $(P<0.05)$ in carcinoma but not in borderline tumors.

Conclusions: Our data suggest that observed inverse correlation of type IV collagen expression with CD44v6 positivity in surface epithelial tumors indicates that these molecules may cooperate in the invasion and progression of ovarian carcinomas.

Keywords: borderline tumor, ovarian carcinoma, CD44v6, type IV collagen.

\section{Al-Kindy College Medical Journal 2016: Vol. 12 No.2} Page: 34-42

${ }^{*}$ M. B. Ch. B., M.Sc. (Path.). lecturer department of pathology and forensic medicine, Al-Kindy college of medicine, Baghdad University.email:hamammy@yahoo.com

${ }^{* *}$ M. B. Ch. B., F.I.C.M.S. (Path.). Assistant professor of pathology, department of pathology and forensic medicine, Al-Kindy college of medicine, Baghdad University.e-mail: mohammed_qortas@yahoo.com.

${ }^{* * *}$ M. B. Ch. B., F.I.C.O.G. lecturer of gynecology and obstetrics, department of gynecology and obstetrics, college of medicine, Al-Iraqia University.e-mail: Israa.talib20@gmail.com .

Received 20 Sep 2015, accepted in final 16th Dec 2015 Corresponding to Mohanad M.Abdul Ghany, Iraq, Baghdad, Department of Pathology and Forensic Medicine, Al-Kindy college of medicine, Baghdad University. Mobile 07808498577, e-mail: hamammy@yahoo.com
A Ithough one of the most important roles of the pathologist is to distinguish borderline tumors from invasive ovarian carcinomas, this distinction is one of the most common problems in ovarian tumor pathology as these tumors have many controversial aspects, such as the histologic criteria for their diagnosis, their biologic behavior, their molecular and biologic relationship to frankly invasive tumors, and their clinical management ${ }^{(1)}$. Ovarian carcinoma carry poor prognosis, one reason for that they exhibits extensive local invasion or frequent regional lymph node metastasis, even at the time of initial diagnosis. The main postulated route of metastatic dissemination of epithelial ovarian cancer is by exfoliation of tumor cells from primary tumors, which migrate and invade surrounding tissues of the peritoneal cavity ${ }^{(2)}$.

The mechanisms involved in metastatic process of ovarian cancer are still incomprehensible, although it is known that several different combinations of genetic abnormalities are responsible for the loss of cell proliferation control, apoptosis, and cell differentiation in invasive ovarian carcinomas ${ }^{(3)}$.

CD44 is a cell-surface adhesion molecule, which is important in cell-cell and cell-matrix adhesion. It was speculated that the overexpression of specific CD44 splice variants v5, v6 could increase the metastatic potential of a tumor by facilitating the expansion of malignant cells into the draining lymph nodes ${ }^{(4)}$. In ovarian carcinoma, the prognostic value of CD44s as well as CD44v6 is still controversial ${ }^{(2,5)}$.

Basement membrane (BM) is a specialized structure of the extracellular matrix ${ }^{(6)}$ and is thought to be a physical barrier for preventing invasion and metastasis of epithelial tumor ${ }^{(7)}$. It is known that proteolytic enzymes may facilitate the breakdown of type IV collagen, which is a major component of basement membranes, and its degradation is an essential event in tumor cell invasion (8). 
The aim of this study is to assess the expression of CD44v6 in relation to type IV collagen in ovarian borderline and malignant surface epithelial tumors to identify any role in invasion and metastasis of ovarian carcinoma and correlation of these markers with clinicopathological parameters.

Methods: This cross sectional study was approved by Institute Review Board of College of Medicine/AlNahrain University. During the period from March/2014 to February/2015, a total of one hundred and one formalin fixed paraffin embedded ovarian tissue of which (60) cases were of serous carcinoma, (10) cases were of endometrioid carcinoma, (8) cases were of mucinous carcinoma, (2) were of clear cell carcinoma and (2) cases were malignant Brenner, with 19 cases of borderline tumor divided as follow (14) cases with serous differentiation and (5) cases of mucinous type were retrieved from the archival materials of Teaching Laboratories and in Medical City and Al-Yarmok hospital as well as AL-Imamen AL-Kadhimain Medical City for the period from January 2011 to December 2014. All the clinicopathological parameters such as age; FIGO pathological stage, histopathological type of ovarian carcinoma and borderline tumors as well as grade of carcinomas were obtained from patients' admission case sheets and pathology reports. Any sample lacking the clinicopathological information was excluded from this study. For each case, one representative (4 micrometer) section was stained with Hematoxylin and Eosin and the histopathological diagnosis was revised, while two (4 micrometer) sections were placed on positively charged slides and stained immunohistochemically using three steps- indirect streptavidin method for monoclonal mouse antibodies including anti CD44v6 antibody, clone (VFF-7) and monoclonal Mouse Anti-Collagen IV antibody, both manufactured by Abcam.

Interpretation of the results of immunohistochemical staining

1. CD44v6 : Brown membranous \& / or cytoplasmic staining pattern of epithelial cells even if staining was focal in tumor cell.

Positive control is tonsil. Technical negative control was obtained by omission of primary antibody.

2. Collagen type IV: Brown staining confined to the basement membrane between surface epithelial cells and stroma is consider positive. Positive control is the human kidney. Technical negative control was obtained by omission of primary antibody.

The results of immunohistochemical expression of the above molecular markers were analyzed in a semiquantitative fashion as follow:

CD 44v6: Was scored semiquantitatively by assessing both staining intensity and percentage of stained cells as follow :

Absent $(=0)$

Weak/moderate $(=1)$
Intense (= 2).

The percentage of stained cells (staining ratio) in relation to the total number cells was estimated as follows:

$0=$ no staining;

$1=$ staining of $1-20 \%$ of cells.

$2=$ staining of $21-50 \%$ of cells.

3 =staining of $51-100 \%$ of cells with final staining index range from $2-5^{(9)}$

Type IV collagen: Presence and extent of staining for type IV collagen were semiquantatively scored as:

$(+++)$ preserved continuous linear staining $51-100 \%$ of basement membrane underlie the neoplastic cells.

$(++)$ moderately reduced linear staining in $21-50 \%$ of basement membrane underlie the neoplastic cells.

$(+)$ highly reduced, predominantly discontinuous linear staining in $1-20 \%$ of basement membrane underlie the neoplastic cells.

(-) no type IV collagen expression ${ }^{(10)}$.

Statistical Analysis Statistical analysis was performed with SPSS V. 16 (statistical package for social sciences) and also Excel 2007 programs. Continuous variables were expressed as mean \pm SEM (standard error of the mean), while categorical variables were expressed as numbers and percentages. Statistical relations between two categorical variables were tested using Chi-square or Fisher exact tests. Relations between categorical and continuous variables were tested using unpaired t-test and ANOVA. Values were considered statistically significant when $p$-value $<0.05$.

Results: The clinicopathological parameters of ovarian borderline tumors and carcinoma cases included in the present study are summarized in (table1) and (figure 1).

CD44v6 immunohistochemical expression Expression of CD44v6 was statistically correlated with histological grade $(p=0.004)$ (table2) and FIGO stage of ovarian carcinoma $(p<0.001)$ (table 4$)$ and borderline tumors $(p=0.001)$ (table 2), CD44v6 expression was recognized in $47(57.3 \%)$ out of 82 ovarian carcinoma cases ( figure 2 and 3 ) compared to $5(26.3 \%)$ cases of borderline tumors however this data failed to achieve statistical significance $(p>0.05)$ this insignificant association of CD44v6 was noticed with other clinicopathologic parameters as shown in (table 2 ).

\section{Type IV collagen immunohistochemical expression}

Type IV collagen was detected immunohistochemically in all the $19(100 \%)$ cases of borderline tumors while it was expressed in only $16(19.5 \%)$ of those with carcinoma (Figure 5), which is highly significant statistically $(P<0.001)$, (Table 3$)$. The majority of advanced ovarian carcinomas was negative for type IV collagen staining as there were inverse association between type IV collagen expression with higher grade $(P=0.004)$ (table 3$)$ and higher stage $(p=0.002)$ ( Table $4)$, however no significance association of type IV collagen with stage in borderline tumor $(p>0.05)$ (Table $5)$. The current study found no significant association between IHC expression of type IV collagen and 
histological types neither in overt carcinoma nor in borderline tumors ( $p>0.05)$ (Tables 3and 5). There was negative correlation between CD44 v6 \& type IV collagen which was statistically significance $(P=0.019)$, in ovarian carcinoma, however this negative correlation failed to achieve statistical significane in borderline tumors(Table 6).

Discussion: Adhesive peculiarities of normal and malignant cells are related to cadherin -catenin complex and CD44 molecule ${ }^{(11)}$. Cellular adhesion (aggregation and migration) and hyaluronate degradation are among several known functions of CD44 ${ }^{(12)}$. Variants of CD44 have been proposed to be important in cancer invasion and metastasis and according to Zhonghua et al ${ }^{(13)}$ the expression of CD44v6 is closely related to carcinoma metastasis and appears to be more suitable as a metastatic marker.

The current study showed significant association between FIGO stages of ovarian carcinoma and CD44v6 immune expression, the expression were increased with higher stage of ovarian carcinoma ( $p$ $<0.001)$. These findings were in agreements with Shi et al $(p<0.05)^{(14)}$, Zhou et al $(p<0.05)^{(15)}$ and Zhu Gai Bian $(P<0.05)^{(16)}$.

The current study also demonstrate increase in CD44v6 expression with loss of differention of malignant cells of in ovarian carcinoma ( $p=0.004)$ this tendency for increase CD44v6 expression along with increase grade of ovarian tumor had been demonstrated by several previous studies like Bar et al. $(P=0.01)^{(10)}$, Shi et a $(p<0.05)^{(14)}$, Zhou et al $(p<0.05)^{(15)}$ and Ryabtseva et al $(p<0.05)^{(17)}$. The positive correlation between histological grade, FIGO stage and expression of CD44v6 may indicate that this marker play an important role predicting the prognosis of patient with non-benign surface epithelial tumors. Regarding the expression of CD44v6 in relation to histological types of ovarian tumors, this study showed no statistically meaningful correlation neither among different types of invasive ovarian carcinoma, nor between the 2 subtypes of borderline tumors with $(P>0.05)$ this were in agreement with Shi et $\mathrm{al}^{(14)}$ and Zhou et al ${ }^{(15)}$. Comparing CD44v6 expression in carcinoma versus borderline groups, the expression was higher among invasive carcinoma group $(57.3 \%)$ than borderline tumor $(26.3 \%)$, however this difference didn't achieve statistical significance ( $\mathrm{P}=$ 0.228), these results were in concordance with Zagorianakou et $\mathrm{al}^{(18)}(50 \%$ vs. $42.9 \%)$ and Hong et al. ${ }^{(19)}(40 \%$ vs. $27 \%)$. On contrary Zhu Gai Bian ${ }^{(16)}$ prove a significant difference among the two groups with $(P<0.001)$, this may attributed to larger sample of borderline tumors ( 32 cases ) compared to (19 cases) in the current study,(15 and 14 cases) in Hong et al ${ }^{(19)}$ and Zagorianakou et al $^{(18)}$ respectively.

Collagens and laminin are major components of basement membrane involved in cell-matrix interaction and tumor progression ${ }^{(20)}$. Breakdown of basement membrane with loss of collagen IV is believed to be an essential step for tumor invasion and metastasis and it is believed to be a result of increased degradation by type IV collagenases ${ }^{(21)}$. A hallmark of carcinomas of the ovary and other epithelial cells is loss of a continuous basement membrane as many studies conclude ${ }^{(22,23)}$, The current study was in tune with these findings as we found no continuous linear expression of type IV collagen in any of 82 carcinoma cases. On the other hand we found that $13(68.4 \%)$ out of 19 case with borderline ovarian tumors express the marker in linear continuous manner, this difference in expression between borderline and invasive carcinoma yield a highly significant association $(P<0.001)$, however, the current study showed that $16(19.5 \%)$ cases with ovarian carcinoma expressed type IV collagen in moderate or severe reduced manner, this positive expression of type IV collagen in invasive carcinoma cases was found by other authors, Capo-Chichi et $\mathrm{al}^{(24)}$ reported that of 50 primary ovarian tumors, $6 \%$ were positive for the type IV collagen while Määttä et $\mathrm{al}^{(25)}$ shows that ovarian carcinomas express significant amounts of BM proteins around tumor islands. these results suggest that the ability to express and deposit BM proteins in general is not lost during malignant transformation. Conversely a proportion of borderline tumors included in the current study showed incomplete expression of type IV collagen a finding that were noticed also in Nictolis et al ${ }^{(26)}$ and Visser et al studies ${ }^{(27)}$

This focal defects in expression of type IV collagen in borderline tumors may indicate early invasive growth, or it could be technical problems related to recovery of masked antigens during the formalin fixation process. Thus, we should emphasize that basement membrane immunostaining should always be evaluated in association with conventional morphology.

According to Stenbäck and his colleague ${ }^{(28)}$, Kuwashima et $\mathrm{al}^{(29)}$ and Mikami et $\mathrm{al}^{(30)}$, the absence of collagen IV and laminin basement membrane associates with dedifferentiation of tumor cells.

The current study showed that there was a general tendency for the grade I tumors to contain more BM immunoreactivity than did grades II and III tumors giving a significant association ( $P=0.004)$.

In the current study we also observed that the progression of ovarian carcinomas stage was associated with decreased expression of type IV collagen with a linear trend for loss of expression of the marker from stage I to stage IV $(P=0.002)$. This positive correlation of type IV collagen with (FIGO) stage of ovarian carcinoma was notice also by Bar et al $^{(10)}$ and Attila F. ${ }^{(31)}$.

We could conclude that the lack of type IV collagen expression in carcinoma cells in advance stages of ovarian carcinoma may reflect their metastatic properties and could be a characteristic feature of cells which acquire more aggressive malignancy phenotype.

However no statistically meaningful correlation was found between stage of tumor and expression of type IV 
collagen in borderline tumors $(P=0.312)$ which could be due to small sample size \& clustering of the cases within stage I.

In some studies, the presence or absence of collagen IV was associated with particular histologic subtypes of ovarian carcinomas $^{(32,33)}$.

The current study showed no statistically meaningful correlation between histological subtypes ovarian carcinoma or that of borderline tumors with expression of type IV collagen $(P>0.05)$.

This were in agreements with Bar et al ${ }^{(10)}$, differences with the earlier results may be due to differences in tissue sampling, antibodies and methods used.

There are few data concerning the correlations between CD44v6 and collagen IV whether in invasive carcinoma or borderline ovarian lesions.

Our findings in this field found that CD44v6 expression was inversely correlated with the type IV collagen expression in both borderline tumors and ovarian carcinoma, this association were statistically significant in carcinomas $(p=0.019)$ but not in borderline tumors $(p=0.679)$, this were in agreement with Bar et $\mathrm{al}^{(10)}$ and may suggest an active role of CD44v6 in tumor expansion.

Conclusion : We concluded that the associations observed in this study between CD44v6 and type IV collagen expression may reflect the interaction between them, and may indicate that the process of ovarian tumor invasion and metastasis requires complex changes in various molecules, which play important role in tumor progression.

Author contributions: All authors contributed to this manuscript. They coordinated study subject recruitment, implementation and progress of this study, and helped with data interpretation and manuscript organization and editing.

Conflict of Interest: All authors have no conflicts of interest

Funding: This research was funded by College of Medicine/Al-Nahrain University.

Acknowledgment: Special thanks to all staff members of pathology and microbiology departments in AL-Nahrain University/ Collage of Medicine for their valuable help and advice.

\section{List of abbreviations:}

- $\quad$ BM: basement membrane

- FIGO: International Federation of Gynecology and Obstetrics

- IHC: Immunohistochemical.

- $\quad$ SI : Staining index
Table 1: clinicopathological parameters of borderline tumors and invasive ovarian carcinoma cases.

\begin{tabular}{|c|c|c|}
\hline \multicolumn{2}{|l|}{ Parameters } & $\begin{array}{l}\text { Values } \\
\text { No.(\%) }\end{array}$ \\
\hline \multirow{2}{*}{$\begin{array}{l}\text { Histopathological } \\
\text { diagnosis }\end{array}$} & borderline tumors & 19 \\
\hline & ovarian carcinoma & 82 \\
\hline \multirow{2}{*}{$\begin{array}{l}\text { Age :Mean range } \\
\pm \text { SEM (years) }\end{array}$} & borderline tumors & $\begin{array}{c}38.05 \pm \\
2.61 \\
(18-62)\end{array}$ \\
\hline & ovarian carcinoma & $\begin{array}{c}57.89 \pm \\
1.13 \\
(30-85)\end{array}$ \\
\hline \multirow{5}{*}{$\begin{array}{l}\text { Histopathological } \\
\text { types of ovarian } \\
\text { carcinoma }\end{array}$} & Serous & $60(73.2 \%)$ \\
\hline & Mucinous & $8(9.8 \%)$ \\
\hline & Endometrioid & $\begin{array}{c}10 \\
(12.2 \%)\end{array}$ \\
\hline & $\begin{array}{ll}\text { Clear } & \text { cell } \\
\text { carcinoma } & \end{array}$ & $2(2.4 \%)$ \\
\hline & Malignant Brenner & $2(2.4 \%)$ \\
\hline \multirow{2}{*}{$\begin{array}{l}\text { Histopathological } \\
\text { types of } \\
\text { borderline tumors }\end{array}$} & Serous & $14(74 \%)$ \\
\hline & Mucinous & $5(26 \%)$ \\
\hline \multirow{3}{*}{$\begin{array}{l}\text { Grade of ovarian } \\
\text { carcinoma }\end{array}$} & Well-differentiated & $30(37 \%)$ \\
\hline & $\begin{array}{l}\text { Moderately- } \\
\text { differentiated }\end{array}$ & $34(41 \%)$ \\
\hline & $\begin{array}{l}\text { Poorly- } \\
\text { differentiated }\end{array}$ & $18(22 \%)$ \\
\hline
\end{tabular}

- SEM: standard error of the mean. No.: number.

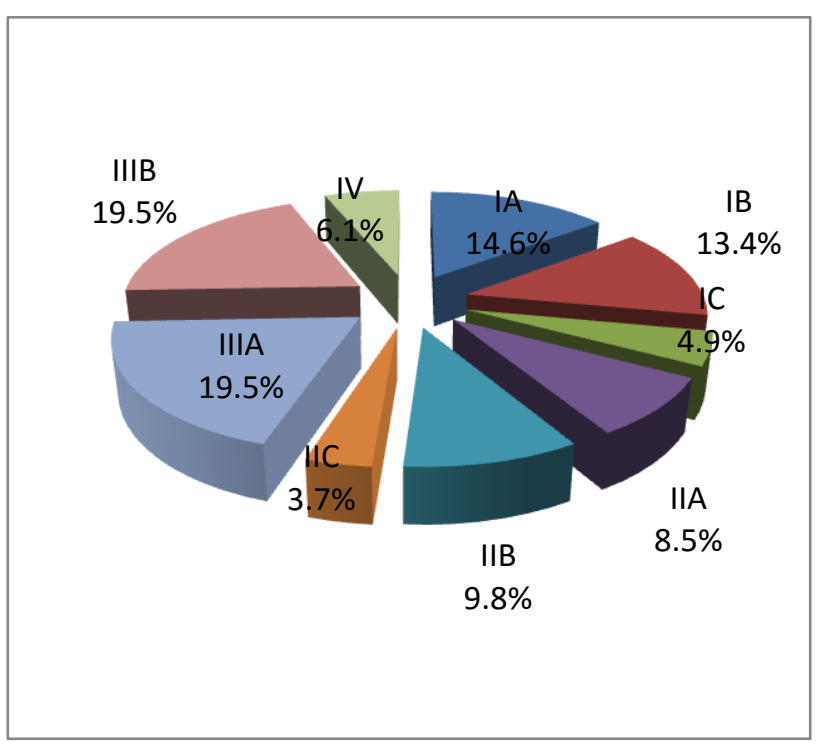




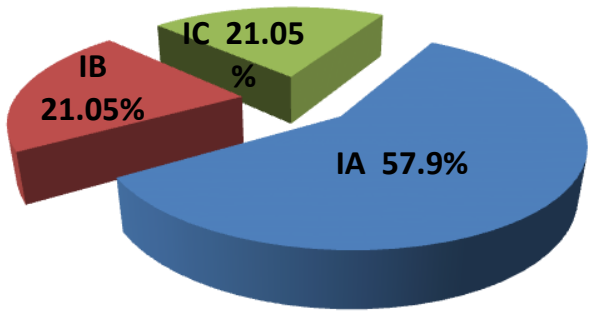

\begin{tabular}{|c|c|c|c|c|}
\hline & $\begin{array}{c}\text { Malignant } \\
\text { Brenner } \\
\text { No. (\%) }\end{array}$ & $1(50 \%)$ & |1(50.0\%) & \\
\hline \multirow{3}{*}{$\begin{array}{l}\text { Grade of invasive } \\
\text { carcinoma }\end{array}$} & G1 No. (\%) & $12(40.0 \%)$ & $18(60.0 \%)$ & \multirow{3}{*}{0.004} \\
\hline & G2 No. (\%) & 19 (55.9\%) & $15(44.1 \%)$ & \\
\hline & G3 №. (\%) & $16(88.9 \%)$ & $2(11.1 \%)$ & \\
\hline \multirow{3}{*}{$\begin{array}{c}\text { Stage of borderline } \\
\text { tumors }\end{array}$} & IA N (\%) & $0(0)$ & 11(100\%) & \multirow{3}{*}{0.001} \\
\hline & IB N (\%) & $1(25.0 \%)$ & $3(75.0 \%)$ & \\
\hline & IC N (\%) & $4(100 \%)$ & $0(0)$ & \\
\hline
\end{tabular}

Figure 1 Pie charts showing distribution of ovarian carcinoma cases (left) and borderline tumors (Right) according to FIGO staging system.

SEM: standard error of the mean, No.: number, G1: well differentiated, G2: Moderately-differentiated, G3: Poorlydifferentiated

Table 3: Association of type IV collagen immunohistochemical expression with clinicopathological parameters of ovarian carcinoma. borderline tumors, and ovarian carcinoma.

\begin{tabular}{|c|c|c|c|c|}
\hline \multicolumn{2}{|c|}{ Clinicopathological parameter } & \multirow{2}{*}{\begin{tabular}{|c|}
$\begin{array}{c}\text { Positive } \\
\text { CD44v6 }\end{array}$ \\
$42.80 \pm 5.17$
\end{tabular}} & \multirow{2}{*}{\begin{tabular}{|c|}
$\begin{array}{c}\text { Negative } \\
\text { CD44v6 }\end{array}$ \\
$36.36 \pm 3.01$
\end{tabular}} & \multirow{2}{*}{\begin{tabular}{|c|}
$\begin{array}{c}P- \\
\text { value }\end{array}$ \\
0.245
\end{tabular}} \\
\hline \multirow{2}{*}{$\begin{array}{c}\text { Age (years) } \\
\text { (mean } \pm \text { SEM) }\end{array}$} & $\begin{array}{c}\text { Borderline } \\
\text { tumors } \\
\end{array}$ & & & \\
\hline & $\begin{array}{c}\text { Ovarian } \\
\text { carcinoma } \\
\end{array}$ & $59.30 \pm 1.56$ & $56.00 \pm 1.62$ & 0.336 \\
\hline \multirow{2}{*}{$\begin{array}{l}\text { Histopathological } \\
\text { diagnosis }\end{array}$} & $\begin{array}{c}\text { Borderline } \\
\text { tumors } \\
\end{array}$ & $5(26.3 \%)$ & $14(73.7 \%)$ & \multirow[t]{2}{*}{0.228} \\
\hline & $\begin{array}{l}\text { Ovarian } \\
\text { arcinoma }\end{array}$ & $47(57.3 \%)$ & $35(42.7 \%)$ & \\
\hline \multirow{2}{*}{$\begin{array}{c}\text { Histopathological } \\
\text { type of Borderline } \\
\text { tumors }\end{array}$} & $\begin{array}{c}\text { Serous No. } \\
\text { (\%) } \\
\end{array}$ & $4(28.5 \%)$ & $10(71.5 \%)$ & \multirow[t]{2}{*}{0.554} \\
\hline & $\begin{array}{c}\text { Mucinous No. } \\
\text { (\%) }\end{array}$ & $1(20.0 \%)$ & $4(80.0 \%)$ & \\
\hline \multirow{4}{*}{$\begin{array}{l}\text { Histopathological } \\
\text { type of invasive } \\
\text { carcinomas }\end{array}$} & $\begin{array}{c}\text { Serous No. } \\
(\%) \\
\end{array}$ & $38(63.3 \%)$ & $22(36.7 \%)$ & \multirow{4}{*}{0.312} \\
\hline & \begin{tabular}{|c} 
Mucinous No. \\
$(\%)$ \\
\end{tabular} & $4(50.0 \%)$ & |4(50.0\%) & \\
\hline & \begin{tabular}{|c} 
Endometrioid \\
No. (\%) \\
\end{tabular} & 2(20.0\%) & $8(80.0 \%)$ & \\
\hline & $\begin{array}{l}\text { Clear cell } \\
\text { CaNo. (\%) }\end{array}$ & $2(100.0 \%)$ & $0(0)$ & \\
\hline
\end{tabular}

\begin{tabular}{|c|c|c|c|c|}
\hline \multicolumn{2}{|c|}{$\begin{array}{l}\text { Clinicopathological } \\
\text { parameter }\end{array}$} & $\begin{array}{l}\text { Positive } \\
\text { type IV } \\
\text { collagen }\end{array}$ & $\begin{array}{c}\text { Negative } \\
\text { type IV } \\
\text { collagen }\end{array}$ & $\begin{array}{l}\mathrm{P} \text { - } \\
\text { value }\end{array}$ \\
\hline $\begin{array}{l}\text { Age(years) } \\
\text { SEM) }\end{array}$ & (mean \pm & $\begin{array}{l}52.56 \pm 3 \\
02\end{array}$ & $\begin{array}{c}59.18 \pm 1 \\
16 \\
\end{array}$ & $\begin{array}{l}0.02 \\
5\end{array}$ \\
\hline \multirow{2}{*}{$\begin{array}{l}\text { Histopatholog } \\
\text { ical diagnosis }\end{array}$} & $\begin{array}{l}\text { Borderlin } \\
\text { e tumors }\end{array}$ & $\begin{array}{l}19(100 \% \\
1 \\
\end{array}$ & $0(0)$ & \multirow{2}{*}{$\begin{array}{l}<0.0 \\
01\end{array}$} \\
\hline & $\begin{array}{l}\text { Ovarian } \\
\text { carcinom } \\
\text { a }\end{array}$ & $\begin{array}{l}16 \\
(19.5 \%)\end{array}$ & $\begin{array}{c}66(80.5 \\
\%)\end{array}$ & \\
\hline \multirow{5}{*}{$\begin{array}{l}\text { Histopatholog } \\
\text { ical type of } \\
\text { invasive } \\
\text { carcinomas }\end{array}$} & $\begin{array}{l}\text { Serous } \\
\text { No. (\%) }\end{array}$ & $10(16.7 \%)$ & $\begin{array}{c}50 \\
(83.3 \%)\end{array}$ & \multirow{5}{*}{$\begin{array}{l}0.15 \\
0\end{array}$} \\
\hline & $\begin{array}{l}\text { Mucinous } \\
\text { No. (\%) }\end{array}$ & $1(12.5 \%)$ & $7(87.5 \%)$ & \\
\hline & $\begin{array}{l}\text { Endometri } \\
\text { oid } \\
\text { No. (\%) } \\
\end{array}$ & $4(40.0 \%)$ & $6(60.0 \%)$ & \\
\hline & $\begin{array}{l}\text { Clear cell } \\
\mathrm{Ca} \\
\text { No. (\%) }\end{array}$ & $0(0)$ & $2(100.0 \%)$ & \\
\hline & $\begin{array}{l}\text { Malignant } \\
\text { Brenner } \\
\text { No. }(\%)\end{array}$ & $1(50 \%)$ & $1(50.0 \%)$ & \\
\hline
\end{tabular}




\begin{tabular}{|c|c|c|c|c|}
\hline \multirow{3}{*}{$\begin{array}{l}\text { Grade of } \\
\text { invasive } \\
\text { carcinoma }\end{array}$} & $\begin{array}{c}\text { G1 No. } \\
(\%) \\
\end{array}$ & $\begin{array}{l}12 \\
(40.0 \%)\end{array}$ & $18(60.0 \%)$ & \multirow{3}{*}{$\begin{array}{l}0.00 \\
4\end{array}$} \\
\hline & $\begin{array}{c}\text { G2 No. } \\
(\%)\end{array}$ & $4(11.8 \%)$ & $\begin{array}{c}30 \\
(88.2 \%) \\
\end{array}$ & \\
\hline & $\begin{array}{c}\text { G3 No. } \\
(\%)\end{array}$ & $0(0 \%)$ & $\begin{array}{c}18(100.0 \\
\%)\end{array}$ & \\
\hline
\end{tabular}

SEM: standard error of the mean, No.: number, G1: well differentiated, G2: Moderately-differentiated, G3: Poorlydifferentiated.

Table 4: Association of type IV collagen and CD44v6 immunohistochemical expression with stage of ovarian carcinoma

\begin{tabular}{|c|c|c|c|c|}
\hline \multirow[t]{2}{*}{$\begin{array}{l}\text { Stage of } \\
\text { ovarian } \\
\text { carcinom } \\
\text { a }\end{array}$} & \multicolumn{2}{|c|}{$\begin{array}{l}\text { Type IV } \\
\text { collagen } \\
\text { staining } \\
\text { extent }\end{array}$} & \multicolumn{2}{|c|}{ CD44v6 SI } \\
\hline & $\begin{array}{l}\text { Pos } \\
\text { itive }\end{array}$ & $\begin{array}{l}\mathrm{Neg} \\
\text { ative }\end{array}$ & $\begin{array}{l}\text { Posit } \\
\text { ive }\end{array}$ & Negative \\
\hline IA No(\%) & $\begin{array}{l}7(5 \\
8.3 \\
\%)\end{array}$ & $\begin{array}{l}5(41 . \\
7 \%)\end{array}$ & $\begin{array}{c}1(8.3 \\
)\end{array}$ & $11(91.7)$ \\
\hline IB No(\%) & $\begin{array}{l}5(4 \\
5.5 \\
\%)\end{array}$ & $\begin{array}{l}6(54 . \\
5 \%)\end{array}$ & $\begin{array}{c}1(9.1 \\
)\end{array}$ & $10(90.9)$ \\
\hline IC No(\%) & $0(0)$ & $\begin{array}{c}4 \\
(100 . \\
0 \%)\end{array}$ & $\begin{array}{c}2 \\
(50.0 \\
)\end{array}$ & $2(50.0)$ \\
\hline $\begin{array}{c}\text { II A } \\
\text { No(\%) }\end{array}$ & $\begin{array}{l}2(2 \\
8.6 \\
\%) \\
\end{array}$ & $\begin{array}{c}5 \\
(71.4 \\
\%) \\
\end{array}$ & $\begin{array}{c}5(71 . \\
4)\end{array}$ & $2(28.6)$ \\
\hline $\begin{array}{c}\text { II B } \\
\text { No(\%) }\end{array}$ & $0(0)$ & $\begin{array}{l}8(10 \\
0 \%)\end{array}$ & $\begin{array}{c}6(75 \\
)\end{array}$ & $2(25.0)$ \\
\hline $\begin{array}{c}\text { II C } \\
\text { No(\%) }\end{array}$ & $\begin{array}{l}1(3 \\
3.3 \\
\%)\end{array}$ & $\begin{array}{c}2 \\
(66.7 \\
\%)\end{array}$ & $\begin{array}{c}3(10 \\
0)\end{array}$ & $0(0)$ \\
\hline $\begin{array}{c}\text { III A } \\
\text { No(\%) }\end{array}$ & $\begin{array}{l}1(6 . \\
2 \%)\end{array}$ & $\begin{array}{c}15(9 \\
3.8 \% \\
\quad \\
\end{array}$ & $\begin{array}{c}12(7 \\
5)\end{array}$ & $4(25.0)$ \\
\hline $\begin{array}{c}\text { III B } \\
\text { No(\%) }\end{array}$ & $0(0)$ & $\begin{array}{c}16(1 \\
00 \% \\
)\end{array}$ & $\begin{array}{c}12(7 \\
5)\end{array}$ & $4(25.0)$ \\
\hline
\end{tabular}

\begin{tabular}{|c|c|c|c|c|}
\hline IV No(\%) & $0(0)$ & $\begin{array}{c}5 \\
(100\end{array}$ & $\begin{array}{c}5(10 \\
0)\end{array}$ & $0(0)$ \\
\hline P -value & \multicolumn{2}{|c|}{0.002} & \multicolumn{2}{|c|}{$<0.001$} \\
\hline
\end{tabular}

SI: staining index, No.: number

Table 5: Association of type IV collagen immunohistochemical expression with age, stage and types of borderline tumors.

\begin{tabular}{|c|c|c|c|c|c|}
\hline \multirow{2}{*}{\multicolumn{2}{|c|}{$\begin{array}{c}\text { Clinicopathological } \\
\text { parameter }\end{array}$}} & \multicolumn{3}{|c|}{$\begin{array}{c}\text { Type IV collagen staining } \\
\text { extent }\end{array}$} & \multirow{2}{*}{$\begin{array}{c}P \\
\text { val } \\
\text { ue }\end{array}$} \\
\hline & & $(+)$ & $(++)$ & (+++) & \\
\hline \multicolumn{2}{|c|}{$\begin{array}{l}\text { Age(years) (mean } \pm \\
\text { SEM) }\end{array}$} & $\begin{array}{c}39.00 \pm \\
1.00\end{array}$ & $\begin{array}{c}35.75 \pm \\
7.45\end{array}$ & $\begin{array}{c}38.62 \pm \\
3.24\end{array}$ & $\begin{array}{l}0.9 \\
11\end{array}$ \\
\hline \multirow{2}{*}{$\begin{array}{l}\text { Histopathol } \\
\text { ogical type }\end{array}$} & \begin{tabular}{|l} 
Serou \\
s \\
No.
\end{tabular} & \begin{tabular}{||c}
2 \\
$(14.3 \%)$
\end{tabular} & $\begin{array}{c}2 \\
(14.3 \%)\end{array}$ & $\begin{array}{c}10 \\
(71.4 \%)\end{array}$ & \multirow[t]{2}{*}{$\begin{array}{l}0.5 \\
77\end{array}$} \\
\hline & \begin{tabular}{|l} 
Mucin \\
ous \\
No. \\
(\%) \\
\end{tabular} & $0(0) \%$ & $2(40.0 \%)$ & $\begin{array}{c}3 \\
(60.0 \%)\end{array}$ & \\
\hline \multirow{3}{*}{ stage } & $\begin{array}{l}\text { IA No. } \\
(\%)\end{array}$ & $0(0)$ & $3(27.3 \%)$ & $8(72.7 \%)$ & \multirow{3}{*}{$\begin{array}{l}0.3 \\
12\end{array}$} \\
\hline & $\begin{array}{ll}B & \text { No. } \\
(\%)\end{array}$ & $1(25.0 \%)$ & $0(0)$ & $\begin{array}{c}3 \\
(75.0 \%)\end{array}$ & \\
\hline & $\begin{array}{l}\text { IC No. } \\
(\%)\end{array}$ & $1(25.0 \%)$ & $1(25.0 \%)$ & $2(50.0 \%)$ & \\
\hline
\end{tabular}

SEM: standard error of the mean, No.: number

Table 6 Correlation between IHC expression of CD 44v6 and IHC expression of Type IV collagen in borderline and malignant ovarian tumors.

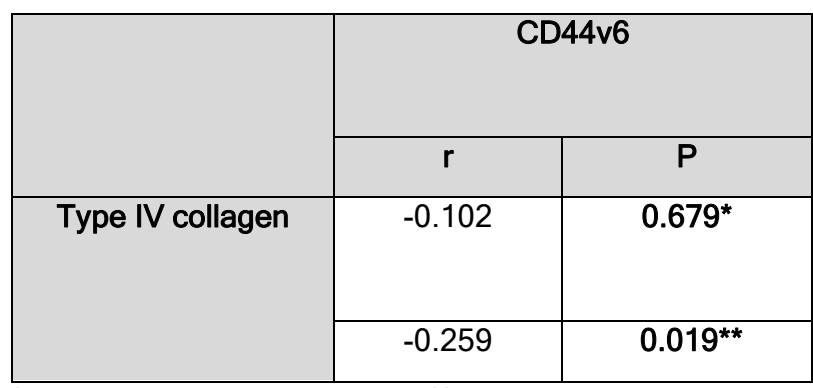

*in ovarian borderline tumors, ${ }^{* *}$ in invasive carcinomas 


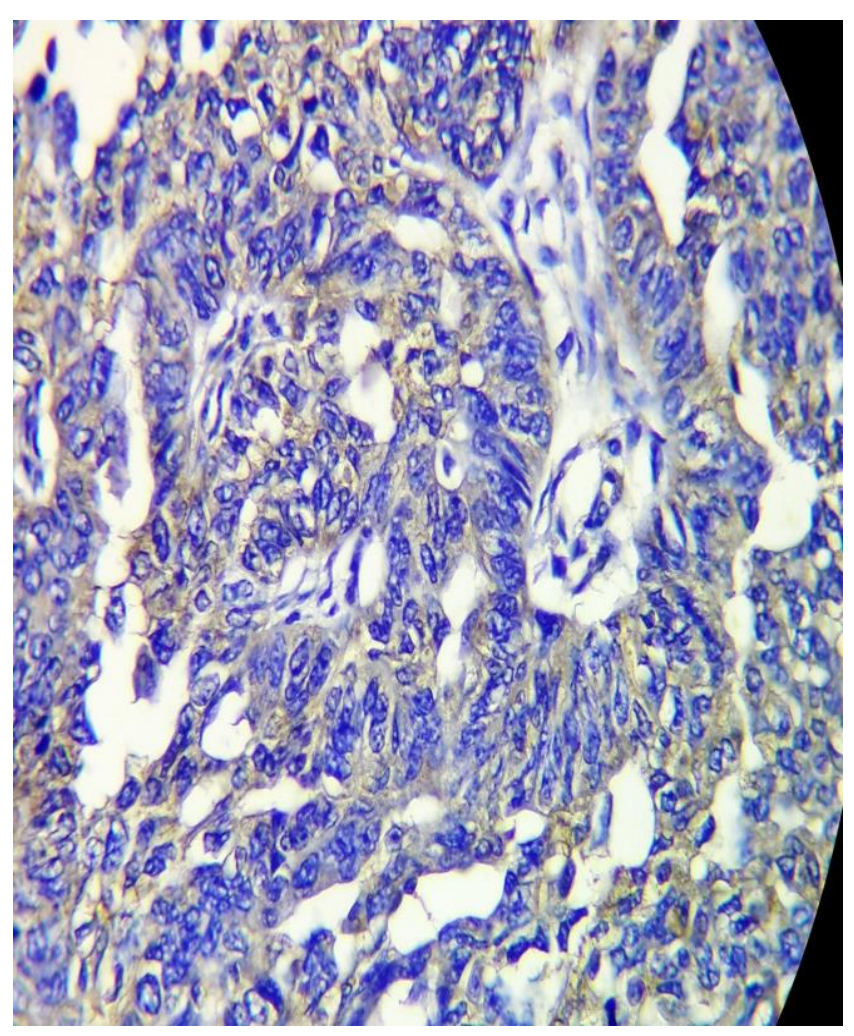

Figure 2 Moderately differentiated serous carcinoma stained with anti CD44v6 showing positive brown cell membrane\&/or cytoplasmic immunostaining with scoring index 4, (40x).

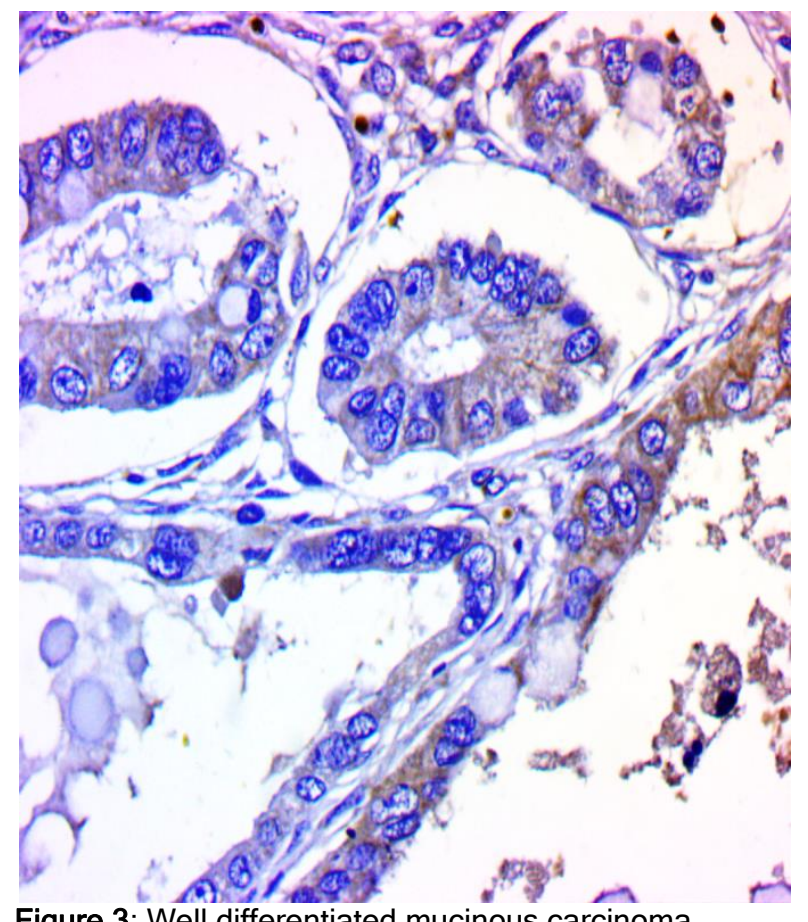

Figure 3: Well differentiated mucinous carcinoma stained with anti CD44v6 with positive brown cytoplasmic and cell membrane with scoring index 3 , (40X).

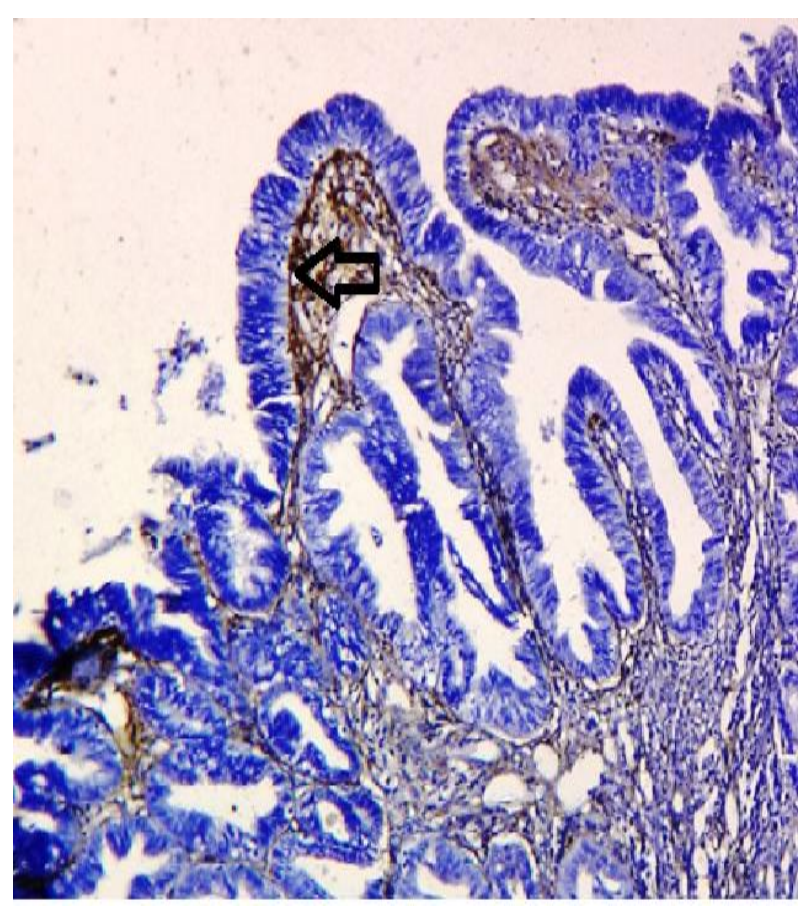

Figure 4: IHC of serous borderline tumor with anti type IV collagen showing continuous linear (+++), expression of type IV collagen, (arrow), (10X).

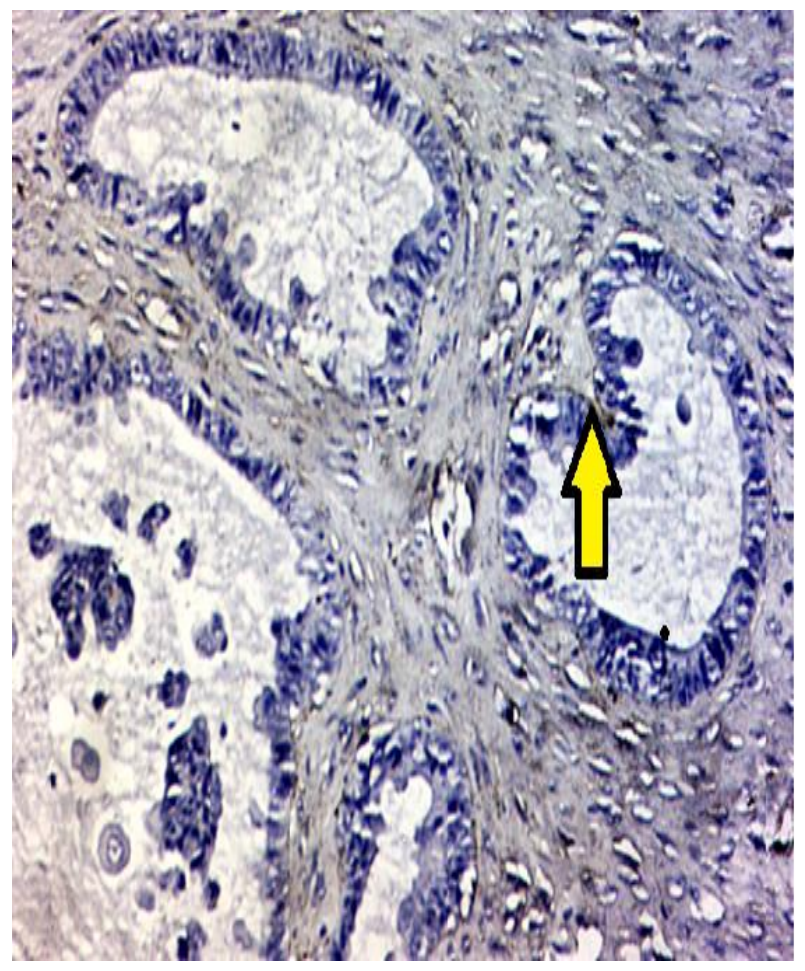

Figure 5: IHC of serous carcinoma with highly reduced $(+)$, expression of type IV collagen, the linear staining of basement membrane underlie the neoplastic cells were less than $20 \%$ (arrow) (10X) 


\section{References.}

1. Seidman JD, Soslow RA, Vang R, et al. Borderline ovarian tumors: diverse contemporary viewpoints on terminology and diagnostic criteria with illustrative images. Hum Pathol. 2004;35: 918-933.

2. Berner HS, Davidson B, Berner A, et al. Expression of CD44 in effusions of patients diagnosed with serous ovarian carcinoma-diagnostic and prognostic implications. Clin Exp Metastasis 2000;18:197-202.

3. Engers R, Gabbert HE. Mechanisms of tumor metastasis: cell biological aspects and clinical implications. J Cancer Res Clin Oncol 2000; 126:682- 92.

4. Salles G, Zain M, Jiang WM, et al. Alternatively spliced CD44 transcripts in diffuse large-cell lymphomas: characterization and comparison with normal activated B cells and epithelial malignancies. Blood 1993;82:3539- 47.

5. Yorishima T, Nagai N, Ohama K. Expression of CD44 alternative splicing variants in primary and lymph node metastatic lesions of gynecological cancer. Hiroshima J Med Sci 1997;46(1):21 -9.

6. Yurchenco PD, Schittny JC. Molecular architecture of basement membranes. FASEB J. 1990;4: 157790.

7. Oka Y, Naito I, Manabe K, Sado Y, Matsushima H, Ninomiya $Y$, et al. Distribution of collagen type IV a1-6 chains in human normal colorectum and colorectal cancer demonstrated by immunofluorescence staining using chain-specific epitope-defined monoclonal antibodies. J Gastroenterol Hepatol 2002;17:980- 6.

8. Nelson AR, Fingleton B, Rothenberg ML, Matrisian LM. Matrix metalloproteinases: biologic activity and clinical implications. J ClinOncol 2000;18:1135- 49.

9. Mahdi NH, Abdulfattah A, Ganem H: ovarian cancer in Alexanderia from 1988-1997, trends and survival. Eastern Mediterranean Health Journal.1999;5:727.

10. Bar JK, Grelewski P, Popiela A, et al. Type IV collagen and CD44v6 expression in benign, malignant primary and metastatic ovarian tumors: correlation with $\mathrm{Ki}-67$ and p53 immunoreactivity. Gynecol Oncol 2004, 95(1):23-31.

11. Nelson WJ. Regulation of cell-cell adhesion by the cadherin- catenin complex. Biochem Soc Trans 2008; 36: 149-55.

12. Underhill C. CD44: the hyaluronan receptor. J Cell Sci 1992;103:293-8.

13. Zhonghua Fu Chan Ke Za Zhi. Study on the relationship between CD44v6 p53 gene mutation and ovarian carcinoma metastasis. 2000; 35(4):225-8. [Article in Chinese] abstract.

14. Jun Shi, Zhou Zhou, Wen Di, et al. Correlation of CD44v6 expression with ovarian cancer progression and recurrence. BMC Cancer. 2013; 13:182.

15. Dang-xia Zhou,Yun-xia Liu, Ya-hong Xue. Expression of CD44v6 and Its Association with
Prognosis in Epithelial Ovarian Carcinomas. Pathology Research International. 2012; Article ID 908206, 5 pages.

16. ZhuGaiBian. Epithelial ovarian tumor tissues OPN, CD44v6, MMP-2 expression and significance. Master's thesis Year: 2008.

17. O.D. Ryabtseva, N.Yu. Lukianova, Yu.A. Shmurakov. et al. significance of adhesion molecules expression for estimation of serous ovarian cancer prognosis. Exp Oncol. 2013; 35(3): 211-218.

18. N. Zagorianakou, D. Stefanou, G. Makrydimas, CD44s Expression, in Benign, Borderline and Malignant Tumors of Ovarian Surface Epithelium. Correlation with p53, Steroid Receptor Status, Proliferative Indices (PCNA, MIB1) and Survival. Anticancer Research. 2004; 24: 1665-1670.

19. Hong SC, Song JY, Lee JK, et al. Significanceof CD44v6 expression in gynecologic malignancies. J Obstet Gynaecol Res. 2006; 32(4):379-386.

20. Watanabe N, Nakajima I, Abe S, et al. Staining pattern of type IV collagen and prognosis in early stage adenocarcinoma of the lung. J Clin Pathol. 1994;47:613-5.

21. Crawford HC, Matrisian LM. Tumor and stromal expression of matrix metalloproteinase and their role in tumor progression. Invasion Metastasis. 1994;14: 234-245.

22. Siegal GP, Barsky SH, Terranova VP, et al. Stages of neoplastic transformation of human breast tissue as monitored by dissolution of basement membrane components. An immunoperoxidase study. Invasion Metastasis. 1981;1(1):54-70.

23. Stenback F, Wasenius VM. Basement membrane structures in tumors of the ovary. Europ $\mathrm{J}$ Obstet Gynec Reprod Biol. 1985; 20:357-371.

24. Capo-Chichi CD, Smith ER, Yang DH, et al. Dynamic alterations of the extracellular environment of ovarian surface epithelial cells in premalignant transformation, tumorigenicity, and metastasis. Cancer 2002 ; 95(8):1802-15.

25. Marko Määttä, Ralf Bützow, Jani Luostarinen et al. Differential expression of laminin isoforms in ovarian epithelial carcinomas suggesting different origin and providing tools for differential diagnosis. Journal of Histochemistry \& Cytochemistry. 2005; 53(10): 1293-1300.

26. De Nictolis M, Garbisa S, Lucarini $G$ et al.72kilodalton type IV collagenase, type IV collagen, and $\mathrm{Ki} 67$ antigen in serous tumors or the ovary: a clinicopathologic, immunohistochemical, and Serological study. Int J Gynecol Pathol. 1996;15(2):102-9.

27. Visser R, Arends JW, Bosman FT.Basement membrane patterns in borderline tumors of the ovary. An immunohistochemical study with antibodies to laminin and type IV collagen. Int $J$ Gynecol Cancer. 1995; 5(4):286-290. 
28. Stenback F, Wasenius VM. Basement membrane structures in tumors of the ovary. Europ $\mathrm{J}$ Obstet Gynec Reprod Biol. 1985; 20:357-371.

29. Kuwashima Y, Uehara T, Kurosumi M, et al. Basement membrane status in undifferentiated carcinomas of the ovary. Immunohistochemical distribution of type IV collagen and laminin. Eur J Gynaecol Oncol. 1995;16:181-186.

30. Mikami Y, Hata S, Melamed J, et al. Basement membrane material in ovarian clear cell carcinoma: correlation with growth pattern and nuclear grade. Int J Gynecol Pathol. 1999;18:52-57.
31. Attila Fenyvesi. The prognostic significance of type IV collagen expression in colorectal carcinomas. Archive of Oncology 2003;11(2):65-70.

32. Orre M, Rogers PA. Reduced vascular basementmembrane immunostaining in mucinous tumours of the ovary. Int J Cancer. 1998;79:139-143.

33. Yang DH, Smith ER, Cohen C, et al. Molecular events associated with dysplastic morphological transformation and initiation of ovarian tumorigenicity. Cancer. 2002;94:2380- 2392. 